\section{BLAŻEJ OSOWSKI}

Uniwersytet im. Adama Mickiewicza w Poznaniu, Polska https://orcid.org/0000-0002-4226-1378
Copyright and License: Copyright by Instytut Języka Polskiego PAN, Kraków 2021. This article is published under the terms of the Creative Commons Attribution - NoDerivatives 4.0 International (CC BY- ND 4.0) License (https:// creativecommons.org/licenses/by-nd/4.0/legalcode.pl).

\title{
ŚWIADOMOŚĆ JĘZYKOWA NA TEMAT GWARY WŚRÓD MIESZKAŃCÓW KONINA I OKOLIC
}

Słowa kluczowe: świadomość językowa, gwara, dialektologia, socjolingwistyka, region Konina.

\section{STRESZCZENIE}

W artykule analizowano wyniki ankiety internetowej dotyczącej świadomości językowej na temat gwary i przeprowadzonej wśród mieszkańców Konina i okolic. Jest to teren ciekawy ze względów socjologicznych (intensywny rozwój miasta w latach 60. i 70. XX wieku, szybkie uprzemysłowienie regionu i liczne migracje) oraz językowych (pogranicze dialektalne oraz wpływ języka przyniesionego przez dawnych migrantów). Badano postawy, jakie wskazana grupa zajmuje wobec gwary, jak ocenia tę odmianę języka i czy się nią posługuje. Analiza 147 ankiet daje możliwość uwzględnienie takich kryteriów, jak wiek, płeć, wykształcenie, miejsce zamieszkania. Dodatkowym celem tekstu jest sformułowanie wniosków na temat wykorzystania ankiety internetowej jako narzędzia w badaniu świadomości językowej na temat gwary.

Większość opinii ankietowanych znajduje potwierdzenie w literaturze dialektologicznej, przy czym ankietowani nie zaobserwowali cech pogranicznych (głównie wpływy mazowieckie) badanego terenu. Wobec gwary ankietowani najczęściej przyjmowali postawę naturalną, liberalną lub leseferyzm, natomiast młodych ankietowanych często charakteryzowało podejście zgodne z kategorią egzotyczności.

Przy odpowiednio dużej grupie badawczej ankieta uzyskuje szeroką reprezentację społeczną. Uwzględnienie w badaniu świadomości językowej na temat gwary nie tylko opinii mieszkańców terenów wiejskich daje szerszą perspektywę.

\section{WSTEPP}

Okolice Konina zależnie od koncepcji badawczej są klasyfikowane jako gwary pogranicza Kujaw (Nitsch 1968) lub Wielkopolski wschodniej o różnym zasięgu geograficznym - mniejszym u Stanisława Urbańczyka (1962: mapa nr 3) i większym u Zenona Sobierajskiego $(2001,68)^{1}$. O gwarach okolic Konina możemy mówić ze względu na istnienie na tym terenie ośrodka administracyjnego, kulturowego i gospodarczego w Koninie, który oddziaływał na ludność okolicy (Zagórski 1991). Ponadto miasto

\footnotetext{
${ }^{1}$ Jego koncepcja zmieniała się w czasie - por. Osowski 2015, 360-361.
} 
w latach 60. i 70. XX wieku przeżywało intensywny rozwój - od miejscowości niespełna dwudziestotysięcznej do miasta z ok. 75 tys. mieszkańców. Pograniczny charakter gwar oraz przemiany społeczne i gospodarcze skłaniają, aby zadać pytanie: jaki stosunek do gwar ma ludność mieszkająca na tym terenie? Z jednej strony - podłoże gwarowe skonfrontowano z polszczyzną ogólną, a z drugiej - warunki życia na wsi uległy gwałtownemu przeobrażeniu w wyniku powstania prężnego ośrodka miejskiego, szybkiej industrializacji oraz zwiększonej mobilności ludności. Zmiany wywołane powyższymi zjawiskami w zakresie cech językowych badał w latach 90. XX wieku Zygmunt Zagórski (1991), niniejszy tekst jest natomiast poświęcony kwestiom świadomości językowej w drugiej dekadzie XXI wieku.

Badany obszar charakteryzowali przy okazji ogólnokrajowych opisów gwar Kazimierz Nitsch (1957), Karol Dejna (1993) i Halina Karaś (Dialekty i gwary...) $)^{2}$. Charakterystykę gwar na terenie Wielkopolski przedstawili Adam Tomaszewski (1934) i Monika Gruchmanowa (2003), o gwarze Kramska w powiecie konińskim pisał Piotr Bąk (1960, $1968)^{3}$, a o wsiach wokół Konina - Zygmunt Zagórski (1991).

W niniejszym tekście nie podjęto systemowego opisu gwar, lecz przedmiotem zainteresowania uczyniono kwestie świadomości językowej. Jest to umiejętność metapoznawcza człowieka, przejawiająca się zdolnością do refleksji nad językiem jako systemem abstrakcyjnych reguł i językową działalnością własną i/lub innych ludzi, grup społeczeństwa, narodu (Cygan 2011, 35). Ze świadomością językową łączą się postawy wobec języka. Pojęcie świadomości językowej można odnieść do gwary jako terytorialnej odmiany języka polskiego i osób nią się posługujących lub mających z nią kontakt - co podejmowano w licznych pracach (np. Cygan 1993, 2011; Grochola-Szczepanek 2008; Kąś 1994; Kucała 1960; Kucharzyk 2002, 2011, 2015, 2019; Kurek 1995; Osowski 2019; Pelcowa 2000, 2004; Piechnik 2015; Sierociuk 2007). Choć potrzeba prowadzenia badań świadomości językowej w środowiskach wiejskich jest oczywista (Cygan 2011, 36), to jednak gdy bada się stosunek społeczeństwa wobec gwary, należy uwzględnić zarówno opinie osób nią się posługujących, jak i pozostałych. Takie podejście przyjęto w pracy.

Główne cele artykułu to analiza świadomości językowej mieszkańców Konina i okolic odnośnie do gwary, określenie postaw, jakie wskazana grupa wobec niej zajmuje, oraz ustalenie, jaki jest stopień znajomości tej gwary. W tym celu przeprowadzono ankietę online, którą udostępniono w internecie za pomocą portalu społecznościowego Facebook oraz innych kanałów. Wzięło w niej udział 147 osób. Jest to grupa zróżnicowana pod względem wieku, płci, wykształcenia, miejsca zamieszkania ${ }^{4}$ - co pozwala

\footnotetext{
${ }^{2}$ Próbki tej gwary ani jej opisu nie podaje natomiast Stanisław Urbańczyk (1962, 73-75).

${ }^{3}$ Piotr Bąk jest także autorem mniejszych tekstów poświęconych temu terenowi, w tym - rozdziału powstałego przy okazji opracowania monografii byłego województwa konińskiego (1986).

${ }^{4}$ Szczegółowa charakterystyka ankietowanych przedstawia się następująco: wiek - 93 osoby do 30 r.ż., 50 - między 31 a 60 r.ż., 3 - powyżej 61 r.ż., jedna osoba nie podała wieku; płeć - 82 kobiety, 50 mężczyzn, 15 osób nie podało tej informacji; wykształcenie - 31 osób ukończyło szkoły wyższe, 23 - szkoły średnie, 26 - uczy się w szkole średniej, 45 - ukończyło szkołę podstawową (zarówno jako ostatni, jak
} 
formułować pewne wnioski uogólniające. W badaniach zróżnicowania współczesnej sytuacji językowej na wsi nacisk kładzie się na kryterium wieku i miejsca zamieszkania (wieś - miasto) (Cygan 1993, 94). W niniejszym tekście postanowiono sprawdzić, czy na stosunek wobec gwary wpływają też płeć i wykształcenie. Dodatkowym celem tekstu jest sformułowanie wniosków dotyczących wykorzystania ankiety internetowej w badaniu świadomości językowej na temat gwary.

Pytania w ankiecie zostały ułożone w pięć sekcji i dotyczyły: 1) gwar okolic Konina, 2) osobistego doświadczenia kontaktu z gwarą, 3) i 4) znajomości słów gwarowych (definiowanie słowa lub podanie słowa na podstawie definicji), 5) metadanych. Na sekcje 1-4 złożyło się 39 pytań. Z uwagi na spójność wywodu przedstawię wybrane aspekty ankiety, tj. analizę odpowiedzi na pytania 1-12 z dwóch pierwszych sekcji.

\section{ANALIZA DANYCH SZCZEGÓŁOWYCH}

Na pytanie 1., czy w okolicach Konina używa się gwary ${ }^{5}$, nieco więcej niż połowa osób biorących udział w badaniu odpowiedziała twierdząco (54\% wszystkich ankietowanych), przy czym 10\% ankietowanych skorzystało z możliwości i uściśliło, gdzie gwarę można usłyszeć. Były to zarówno odpowiedzi ogólne (Konin i okolice; na wsiach; W całym powiecie ${ }^{6}$, jak i wskazujące konkretne miejscowości: Golina, Konin, Kramsk, Lisiec Wielki, Rzgów, Rychwał, Ślesin, 5 osiedle (właśc. osiedle V - część Konina). Te dane przedstawiają się interesująco w kontekście następnego pytania, w którym proszono o odpowiedź, czy gwary używa się w samym Koninie. Tym razem odsetek odpowiedzi pozytywnych był zdecydowanie mniejszy (29\%), co odpowiada poglądowi, że w mieście używa się języka ogólnego, a nie - gwar. $Z$ tego też powodu na pytanie 3. - „Wymień przykłady z gwary Konina lub okolic (wyrazy, powiedzonka, inne cechy językowe)" większość ankietowanych nie udzieliła odpowiedzi lub odpowiedziała „nie wiem”, „nie znam". Pojawiły się także odpowiedzi wprost negujące istnienie odrębnej gwary konińskiej: Typowych wyłacznie dla Konina nie znam; nie ma takich. Jedynie kilka osób spróbowało podać przykłady tak zdefiniowanej gwary, przy czym w większości mamy do czynienia z cechami gwarowymi znanymi szerzej, np. koniniok; laczki; nabierka; lotać, buciory, czopka, kapuśniok; gzik; W d.. Domu u Pani Malinowskiej. Kilka osób podało też wyraz pucha 'autobus'.

Zadano również pytanie: „Czy Twoim zdaniem istnieje specyficzna gwara konińska? Specyficzna, czyli charakterystyczna tylko dla Konina, odmienna od innych gwar”.

\footnotetext{
i pośredni etap edukacji), 9 - szkołę zawodową, 13 - nie podało bliższej charakterystyki w tym zakresie; typ zamieszkiwanej miejscowości: do 20 tys. mieszkańców - 71 osób, między 20 tys. a 50 tys. -21 , powyżej 50 tys. $-54,1$ osoba nie podała tej informacji.

${ }^{5}$ Współcześnie gwara jest tylko jedną z odmian używanych na wsi. Jednak z myślą o jasności formułowania pytań kierowanych do osób niezajmujących się zawodowo językoznawstwem uznano, że wprowadzanie pojęć język mieszkańców wsi, kod językowy, kod mieszany itp. byłoby niekorzystne. Zdecydowano się zatem posługiwać określeniem gwara.

${ }^{6}$ Zachowano pisownię oryginalną.
} 
Aż 84\% ankietowanych odpowiedziało, że nie, co znajduje poparcie w literaturze, ponieważ dotychczas nie opisano takiego zjawiska jak gwara miejska Konina. Było to jednocześnie trudne pytanie, ponieważ nie tylko odwoływało się do własnych doświadczeń (jak dwa wcześniejsze), lecz także wymagało wiedzy o innych gwarach, żeby móc ocenić, czy ewentualna gwara Konina różni się od nich czy nie.

Dwa kolejne pytania miały za zadanie sprawdzić, jakie skojarzenia wśród ankietowanych budzi gwara. W tym celu należało podać do pięciu przymiotników (pytanie 5) i do pięciu dowolnych skojarzeń (pytanie 6) na temat gwary. Odpowiedzi na te dwa pytania można podzielić na kilka grup, które odnoszą się do cech definicyjnych gwary (określam je na podstawie EWoJP, hasło gwara):

- „mowa ludności wiejskiej z niewielkiego terytorium, przeważnie z kilku czy kilkunastu wsi" - w materiale znajdujemy odniesienia do ograniczonego terytorialnie zasięgu gwary (lokalna; regionalny język; język danego regionu; styl mówienia dla danego regionu; dany obszar; dane regiony; miejscowa; regionalizm; województwo; terytorialna; Stownictwo, które pojawia sie tylko na danym obszarze), pojawia się też wskazanie na środowisko wiejskie (ludowa; chtopska; wiejska mowa; rolnik; mowa ludzi pochodzacych ze wsi; ze wsia). Niemniej ankietowani wskazywali też na inne środowiska: [gwara jest łączona] $z$ językiem który byt wykorzystywany kiedyś przez nasze starsze pokolenia, po prostu każde miasto miało swoja gware; miejska; szkolna; młodzieżowa; uczniowska; branżowa; zawodowa; środowiska zawodowe; rzemieślnik. Zatem ankietowani w większości nie widzą różnicy między gwarą ludową, miejską a środowiskową oraz nie rozróżniają gwary i dialektu. Wymieniano także, z jakimi obszarami użycia kojarzy się gwara - dom (na co wskazywał przymiotnik domowa) i targ;

- „różniąca się od języka ogólnego i mowy sąsiednich okolic pewnymi cechami, głównie fonetycznymi i leksykalnymi" - ankietowani w swoich odpowiedziach zwracali uwagę właśnie na te dwie płaszczyzny języka: odmiennosc leksykalna; odmienne, inne słowa; synonimy do różnych wyrazów (np. pyra i ziemniak to te same rzeczy) ${ }^{7}$; Dziwna wymowa; intonacja. Tu też należy wymienić przykłady gwarowego słownictwa podawane przy tym pytaniu: Brachol, fajny, guzik, gwiazdor; gzik, wygogolony; Górajka gira boszowka; Cwańcyś; Bez to; laczki, pyry; zaś, kontenci (zadowoleni), kuma, kumoter, kumoszka; zydel, hebel; pyzy; lelać się, chichrać się, śpiki, tytka; laczki, gira, pierdoty, szkity; lub cechy wymowy, np. inny akcent; zmiekczanie samogłosek (sic!); Żodyn Gupi Mundry Pikny; czymu, bydziesz; Przychódź; Chopie; jo, wim; ziemnioki. Pojedynczo ankietowani zwracali uwagę na cechy z innych podsystemów języka: układ gramatyczny; Zmiana wymowy końcówek wyrazów wodnity, ciapowaty; Odmienne znaczenia. Taki rozkład zauważanych cech gwarowych okazuje się zgodny ze świadomością selekcyjną obejmującą tylko niektóre fragmenty rzeczywistości językowej i wybrane wycinki systemu gwarowego (Pelcowa 2004, 129).

\footnotetext{
${ }^{7}$ Stąd uwagi o różnorodności środków wyrazu w gwarze (bogactwo językowe; urozmaicenie; barwna).
} 
Nie znalazły wśród odpowiedzi ankietowanych potwierdzenia bardziej złożone cechy gwary ustalone w toku badań przez językoznawców (,,podrzędna w stosunku do dialektu”), choć jedna osoba wśród skojarzeń wymieniła dialekt, nie określiła jednak relacji łączącej go z gwarą.

W skojarzeniach uczestników ankiety pojawiają się ponadto odpowiedzi, które nie mieszczą się w przytoczonej definicji, ale w większości można uznać je za celne. Są to wskazania na pokoleniowy zakres użycia gwary (starsze pokolenie; starsi ludzie; dziadkowie), co prowadzi niektórych ankietowanych do wniosku, że jest to odmiana należąca do przeszłości (starodawna; staroświecka; zanikajaca; zapomniana; prawie wymarła; z historią; przeszłość; dawne czasy). Do kategorii dawności nawiązuje kolejna cecha, tj. tradycyjność (tradycyjna; z kultywowaniem tradycji; tradycje ludowe; z rdzennymi zwyczajami danej społeczności), co z kolei pozwala przejść do związku gwary z kulturą (kultura ludowa; obyczaje; foklor; kultura danego terenu). Następną cechą gwar w świetle odpowiedzi ankietowanych jest rodzinność, którą można wpisać w szerszą kategorię 'my - oni' (Z rodzina, Ze znajomymi; wielopokoleniowa; swojska; rodzima; odrębność; inna społeczność; bliskość sasiedzka, bliskie relacje). Ta opozycja jednocześnie niesie wartościowanie ,nasze jest lepsze, ich gorsze” i jest „typowym sposobem samookreślania się, wyznaczania kręgu wspólnoty" (Pelcowa 2004, 35-36), co skłania do wniosku, że gwarze przypisuje się duży potencjał identyfikacyjny, grupotwórczy (silna tożsamość kulturowa; z własna społecznościa; z poczuciem lokalnej odrębności; przynależność, zakorzenienie; z tym gdzie się wychowaliśmy, z tym czego nas uczono).

Zauważono także wykorzystywanie gwary w celach ludycznych (zabawna; śmieszna; Ze śmiechem), przez co gwara kojarzy się ankietowanym także z kategorią luzu językowego (swobodna wypowiedź; ze swobodą; ekspresyjność; z wolnościa słowa; potoczna). Ten z kolei prowadzi do uwag o mniejszym wpływie normy w tej odmianie języka (prosta, nieformalna; z luźna, śmieszna wypowiedzia; naturalna), a przez porównanie ze stanem języka ogólnego - do skojarzeń z niepoprawnością językową, aberracją gwary jako odmiany (niezbyt poprawna; nazywanie poszczególnych rzeczy, przedmiotów czy sytuacji inaczej niż w poprawnej formie j. polskiego; wyśmiewana; śmieszne nielogiczne nazwy; Z czymś nienaturalnym; zniekształcona).

Skojarzenie z brakiem wykształcenia i ogłady skutkuje ujemnym wartościowaniem gwary jako odmiany niekulturalnej w porównaniu z polszczyzną ogólną. Pojawiają się z tym związane przymiotniki (pospolita, dosadna, grubiańska; prostacka; uboga; chaotyczna) oraz rzeczowniki (wstyd, prostota, wieśniactwo; Ciemnota, Gtupota; w tym nazwy negatywnych uczyć: wstyd, zażenowanie). Ponadto ankietowanym gwara kojarzy się z Zacofaniem, Czymś czego nie używam.

Widać zatem w powyższych skojarzeniach dychotomiczny stosunek społeczeństwa do gwar: dezaprobatę i - z drugiej strony - akceptację (Kucharzyk 2019, 9), a także przewartościowanie sposobu postrzegania języka wsi, dokonujące się w polskim społeczeństwie (Kucharzyk 2015, 49).

Jednakże dla większości młodych ankietowanych gwara wiąże się z kategorią egzotyczności - jest językiem innym niż ich (inna; odmienna; nietypowa; dziwna; oryginalna; 
specyficzna; charakterystyczna; niepowtarzalna; obca; unikalna; unikatowa; rzadka; wyjątkowa, wyróżniająca się), co nie dziwi, ponieważ - zdaniem Haliny Pelcowej większość młodego pokolenia już 20 lat temu nie miała gwarowej kompetencji językowej, tj. nie znała gwary własnego terenu i nie umiała się nią posługiwać $(2000,92)$. Obcość gwary przyczynia się wśród osób młodych do problemów z jej zrozumieniem (niezrozumiała; tajemniczość; niszowa; trudna), ale jednocześnie wzbudza ich ciekawość (fascynujaca; interesujaca; ciekawa; warta poznania).

Pytanie 7. zawierało prośbę o podanie pięciu przykładów gwar. Najczęściej wymieniano gwarę śląską (111 odpowiedzi), kaszubską (73), poznańską (69), górską/góralską (68). Inne odpowiedzi zyskały mniej głosów: wielkopolska (28), warszawska (26), podhalańska (13), mazowiecka (8), mazurska (8), krakowska (7), ślesińska (7), częstochowska (6), ochweśnicka (6), pomorska (5), konińska (4), łowicka (4), małopolska (4), zakopiańska (4), cieszyńska (3), kramska (3), lubelska (3), toruńska (3), kielecka (2), kurpiowska (2), podlaska (2); pojedynczo wymieniono następujące przykłady: budzisławska, bydgoska, golińska, kociewska, kresowa, „krzyżacka” (okolice Malborka), kujawska, łódzka, rzgowska, szczecińska.

Powyższy przegląd skłania do wyciągnięcia kilku wniosków. Po pierwsze - jak już wspomniano - ankietowani nie odróżniają pojęć gwary i dialektu, dlatego wymieniano przykłady typu gwara małopolska, mazowiecka, ślaska, wielkopolska. Po drugie obecność sformułowania gwara kaszubska świadczy o tym, że wśród przeciętnych użytkowników polszczyzny zmiana statusu kaszubszczyzny w 2005 roku nie jest faktem powszechnie znanym. Po trzecie - można wyodrębnić grupę nazw tworzonych seryjnie od nazw miejscowości (częstochowska, lubelska, toruńska, szczecińska), w tym-miejscowości z najbliższego otoczenia ankietowanych (budzisławska, golińska, konińska, kramska, rzgowska, ślesińska - od leżących w powiecie konińskim: Budzisławia Kościelnego, Goliny, Konina, Kramska, Rzgowa, Ślesina), nawet jeśli w tych miejscowościach nie potwierdzono lub nie badano gwary. Zapewne ze względu na bliskość terenu wymieniono także gwarę ochweśnicką̨ ${ }^{8}$, która była odmianą społeczną używaną m.in. w okolicach Ślesina9 . Do nazw seryjnych zaliczyć można też odpowiedź gwara pomorska od nazwy regionu (analogicznie do małopolska, mazowiecka itd.).

W pytaniu 8. ankietowani określali swoją postawę wobec gwary. Postawy wobec języka to „ogół względnie trwałych poglądów na język i stanowisk zajmowanych w sprawach językowych, wyrażanych publicznie i uzasadnianych w kategoriach racjonalnych lub emocjonalnych. Tak rozumiana postawa językowa jest głównym składnikiem świadomości językowej osoby albo grupy społecznej” (WSPP 1646). Koncepcja Andrzeja Markowskiego została zaadaptowana do poglądów wobec gwary. Za wspomnianym badaczem wyróżniono 10 postaw i zbudowano odpowiadające im zdania testowe.

\footnotetext{
${ }^{8}$ Jej charakterystykę znaleźć można w: Budziszewska 1957.

${ }^{9}$ Warto dodać, że jak podaje Helena Krasowska (2020, 50-51), w Ślesinie pojawiają się dwujęzyczne tablice (wariant ogólnopolski i ochweśnicki), co ma świadczyć o lokalnym dziedzictwie kulturowym i jest formą promocji gwary. Za zwrócenie na to uwagi dziękuję Szanownym Recenzentom.
} 
Ankietowani mieli możliwość wielokrotnego wyboru zdań, które najlepiej oddawały ich stosunek do gwary.

Najwięcej głosów (po 75) oddano na dwie postawy - naturalną (spontaniczną) oraz liberalizm językowy. Pierwszą reprezentuje zdanie „Doceniam gwarę jako naturalny środek porozumiewania w pewnych środowiskach". Zakłada ona przestrzeganie tzw. normy naturalnej, nieskodyfikowanej, ale mocno uświadamianej, przekazywanej zwyczajowo w danej grupie. Język jest postrzegany jako dobro naturalne, środek, którego używa się tak, a nie inaczej ze względu na zwyczaj przyjęty w danym środowisku. Z kolei liberalizm językowy (,Akceptuję gwarę ze wszystkimi jej innowacjami językowymi, wariantami i formami obocznymi") to postawa bardzo tolerancyjna wobec wszelkich zmian językowych (w tym - zapożyczeń wewnętrznych), form obocznych i wariantywnych w języku.

Mniej głosów (45) oddano na leseferyzm przejawiający się postawą „Akceptuję gwarę, przecież mówi nią tak wiele osób". Osoby wybierające takie stanowisko akceptują te zjawiska językowe, które mają w nim dużą frekwencję (czyli oparcie w uzusie), nie różnicują i nie wartościują elementów języka.

Nieco mniej głosów (33) uzyskał indyferentyzm językowy: „Gwara może sobie istnieć lub nie; jest mi obojętne, jak kto mówi”. Jest to bardziej lub mniej świadoma obojętność wobec kwestii językowych, wynikająca z nietraktowania języka jako wartości, jako czegoś, co nie ma istotnego znaczenia w życiu codziennym i nie wpływa na to życie.

Liberalizm językowy $\mathrm{i}$ indyferentyzm językowy są - zdaniem Andrzeja Markowskiego - najczęstszymi postawami młodzieży (WSPP 1651), co okazuje się znamienne wobec faktu, że 53\% ankietowanych to 18-latkowie lub osoby młodsze. Jednak o ile podobny procent osób młodych (do 30 r.ż.) i w średnim wieku (powyżej 31 r.ż.) wybiera liberalizm językowy (odpowiednio: 51\% i 53\%), o tyle w przypadku indyferentyzmu językowego różnica jest już znacząca: 30\% u młodszych ankietowanych i tylko 8\% u starszych ${ }^{10}$. Postawy młodych wskazują, że w ciągu 20 lat zmienił się ich stosunek wobec gwary - z negatywnego (Kucharzyk 2002, 283) na akceptujący lub obojętny. Jest to ważne o tyle, że świadomość językowa ma decydujący wpływ na konkretne zachowania językowe, a od jej stanu zależy stan języka (Kucharzyk 2011, 29). Choć - jak zaznaczono wcześniej - dla większości młodzieży gwara jest odmianą obcą, to jednak pozytywna lub neutralna postawa tej grupy wiekowej może ułatwić posługiwanie się gwarą tym osobom, które ją znają, ponieważ nie narażą się one na wyśmiewanie czy inne sankcje społeczne.

Do 10 głosów oddano na różne postacie logizowania i puryzmu. Pierwsza z postaw zakłada zgodność wyrażeń językowych z tzw. logiką potoczną, natomiast druga polega na dbałości o czystość języka, tj. dążenie do usuwania z niego lub ograniczania w nim takich elementów, które uznane zostają za niepożądane. Puryzm może mieć charakter nacjonalistyczny, tradycjonalistyczny, elitarny lub egocentryczny.

\footnotetext{
${ }^{10}$ Dla postawy naturalnej wartości procentowe również są zbliżone (52\% i 51\%), natomiast leseferyzm częściej pojawia się w grupie ankietowanych młodych (35\%) niż w średnim wieku (23\%).
} 
Kolejne pytania były związane ze stycznością z gwarą. Na pytanie 9. („Czy mówisz gwarą?”) uzyskano $65 \%$ odpowiedzi „nie”, $22 \%$ - „tak” oraz $13 \%$ innych reakcji. W grupie trzeciej najwięcej odpowiedzi dotyczy częstości używania gwary (czasami; rzadko; nie raz), stopnia nasycenia wypowiedzi elementami gwarowymi (pojedyncze słowa; trochę), kontekstu sytuacyjnego (zależy w jakim towarzystwie; to zależy od miejsca w jakim jestem), kwalifikacji temporalnej (kiedyś używałem) i stylistycznej (czasami używam pojedynczych stów dla śmiechu $)^{11}$. Ankietowani uświadamiają sobie, że mogą nie mieć wystarczających umiejętności, aby określić, czy używają gwary, czy też nie (moge mówić ale nawet o tym nie wiem; może, nieświadomie). Zaskakuje wysoki poziom odpowiedzi pozytywnych, których udzielały osoby młode (por. tabela 1). Tu jednak pozostaje otwartym pytanie, co ankietowani rozumieli pod pojęciem gwary, ponieważ - jak już była o tym mowa wcześniej - w dużej mierze jest to wiedza intuicyjna, niejasna. Możliwe, że pomimo ukierunkowania ankiety na badanie stosunku do gwary okolic Konina ankietowani mieli na myśli inne odmiany terytorialne lub odmiany nazywane przez nieprofesjonalnych użytkowników języka gwarami - por.: Czasami używam pjedynczych słów z gwary poznańskiej lub młodzieżowej.

Tabela 1

\begin{tabular}{|l|c|c|c|}
\hline \multicolumn{4}{|c|}{ Czy mówisz gwarą? } \\
\hline Wiek ankietowanych & $0-30$ r.ż. & $31-60$ r.ż. & 61 r.ż. i więcej \\
\hline Nie & 53 & 40 & 3 \\
\hline Tak & 40 & 10 & 0 \\
\hline
\end{tabular}

W ankiecie $62 \%$ osób biorących udział zadeklarowało płeć żeńską, a 38 \% - męską. Do tych wartości zbliżone okazują się zarówno deklaracje pozytywne (odpowiednio $60 \%$ i 40\%), jak i negatywne (63\% i 37\%) co do używania gwary. Jedynie wśród odpowiedzi precyzujących frekwencję zauważalny stał się - w porównaniu z proporcjami w całej ankiecie - wzrost udziału kobiet (71\%).

Rozkład odpowiedzi twierdzących i przeczących jest skorelowany z typem zamieszkiwanej miejscowości. Mieszkańcy terenów wiejskich oraz małych miast do 20 tys. mieszkańców stanowili w całej ankiecie 49\%, miast średnich 20-50 tys. stanowili $14 \%$, natomiast dużych - 37\%. Odpowiedzi pozytywne oraz dookreślające frekwencję, sytuację użycia itd. częściej pojawiały się wśród mieszkańców wsi i miasteczek (odpowiednio: 66\% i 53\%), natomiast odpowiedzi negatywnych częściej udzielali mieszkańcy miast średnich i dużych (odpowiednio: 17\% i 43\%).

Jeśli chodzi o wpływ wykształcenia, to zgodnie z przewidywaniami osoby, które ukończyły studia wyższe, częściej odpowiadały, że nie używają gwary (37\% odpowiedzi

\footnotetext{
${ }^{11}$ Stylistyczne nacechowanie form gwarowych na tym terenie jest mechanizmem od dawna znanym. O cytowaniu form gwarowych dla żartu językowego lub (ze względu na ich obcość) wyśmiewania pisał już w 1955 roku Piotr Bąk.
} 
negatywnych). Tylko jedna kobieta z tej grupy zadeklarowała mówienie gwarą. Z kolei udział osób z wykształceniem średnim, gimnazjalnym i podstawowym w odpowiedziach pozytywnych (odpowiednio: 24\%, 38\%, 21\%) był wyższy niż w całej ankiecie $(14 \%, 29 \%, 16 \%)$. Wśród uczniów szkół średnich znacząco wyróżnia się odsetek odpowiedzi dookreślających frekwencyjne lub kontekstowe używanie gwary (48\%), co jednak może wynikać z wcześniej omówionych problemów z rozróżnianiem odmian polszczyzny.

Zaskakuje stabilność odpowiedzi twierdzących w perspektywie pokoleniowej. Zgodnie z przewidywaniami ankietowani odpowiadali, że ich rodzice (pytanie 10) i dziadkowie (pytanie 11) częściej mówią gwarą niż oni sami. Te różnice jednak nie mają charakteru skokowego, co należy wiązać z wysokim bazowym poziomem odpowiedzi pozytywnych u ankietowanych. Podobne obserwacje poczyniła Helena Grochola-Szczepanek, badająca używanie wyrazów ogólnopolskich i ich gwarowych odpowiedników w ocenie uczniów wybranych spiskich gimnazjów $(2008,219)$. Przy czym badaczka przypuszcza, że rzeczywisty procent użycia słownictwa gwarowego wśród pokoleń średniego i starszego może być wyższy niż deklarowany przez uczniów. Zdają się za tym przemawiać odpowiedzi na kolejne pytanie: „Czy ktoś z Twojego otoczenia mówi gwarą? Jeśli tak, proszę w pole «Inne» wpisać, kto nią mówi”. Nieco większa grupa ankietowanych ( 84 głosy) odpowiedziała negatywnie, ale aż $43 \%$ biorących udział w badaniu wymieniło osoby - w ich opinii - mówiące gwarą. Najczęściej wymieniano kolegów i znajomych (22 odpowiedzi, np. znajomi za granica; Koledzy ze studiów; kumple z klasy; Koledzy ze wsi; Koledzy z internetu), ale prawie tak samo często pojawiała się rodzina i jej członkowie (19, np. rodzice; wujkowie, ciocie, kuzyni; czasami dziadkowie mieszkający na wsi; babcia częściowo posługiwała się gwara wielkopolska, używała zapożyczeń z języka niemieckiego; moja babcia dziadek ciocia wuja; Mąz, teściowie), sympatie (2: dziewczyna; chłopak). O wiele rzadziej pojawiali się sąsiedzi (5, np. Niektórzy sąsiedzi, głównie starsi ludzie), nauczyciele (1), współpracownicy (1). Ponadto wymieniano duże i zróżnicowane grupy, np. Wszyscy których znam porozumiewaja się gwarą; osoby mieszkające na wsi; mieszkańcy mojego miasteczka. Niekiedy precyzowano geograficznie pochodzenie osób używających gwary, np. kolega, który przeprowadził się z gór; Chłopak ze Śląska; Znajomi z okolic Poznania; pyry 'poznaniacy'.

Tabela 2

\begin{tabular}{|l|c|c|c|}
\hline Czy gwarą mówią... & ankietowani & rodzice ankietowanych & dziadkowie ankietowanych \\
\hline Nie & $65 \%$ & $59 \%$ & $35 \%$ \\
\hline Tak & $22 \%$ & $32 \%$ & $58 \%$ \\
\hline Inne & $13 \%$ & $9 \%$ & $7 \%$ \\
\hline
\end{tabular}




\section{WNIOSKI}

Aby podsumować analizy szczegółowe, należy zwrócić uwagę, że większość opinii ankietowanych znajduje potwierdzenie w literaturze dialektologicznej: brak gwary miejskiej Konina (spowodowany szybkim rozwojem miasta i gwałtowną migracją do niego), gwary ludowe występujące w okolicznych wsiach i jako należące do dialektu wielkopolskiego wolne od specyficznych (sobie tylko właściwych) cech językowych. Ankietowani nie zaobserwowali natomiast cech pogranicznych (głównie wpływy mazowieckie) tego terenu.

Wśród cech gwary jako odmiany językowej wymieniono najważniejsze składniki definicji (występowanie na wsi, cechy leksykalne i fonetyczne), ale jednocześnie zabrakło innych ważnych cech (reprezentujących inne poziomy języka, rozróżnienia gwara - dialekt, gwara wiejska - gwara miejska, gwara ludowa - socjolekt). Ponadto z pojęciem gwary wiążą się - według biorących udział w badaniu - elementy konotacyjne (np. gwara jako język osób starszych, jej funkcja tożsamościowa i kulturotwórcza) i wartościujące: nieco częściej pozytywne niż negatywne. Dlatego też wobec gwary ankietowani najczęściej przyjmowali postawę naturalną, liberalną lub leseferyzm. Młodych ankietowanych często charakteryzowało podejście zgodne z kategorią egzotyczności - gwara jest czymś obcym, przez to niezrozumiałym, ale i wzbudzającym ciekawość.

Poza wiekiem na stosunek do gwary wpływają także wykształcenie oraz miejsce zamieszkania, mniej znacząca jest natomiast płeć ankietowanego.

Jeśli chodzi o wnioski natury ogólniejszej dotyczące wykorzystania ankiety internetowej jako metody zbierania danych w badaniu świadomości językowej na temat gwary, to należy zaznaczyć, że umożliwia ona pozyskanie dużej liczby informacji w stosunkowo krótkim czasie. Można więc z powodzeniem prowadzić badania ilościowe, natomiast nawet uwzględnienie w ankiecie pytań otwartych nie zastąpi możliwości dopytywania, zadawania pytań pogłębionych przez badacza w trakcie badań jakościowych.

Pod warunkiem, że grupa badawcza okaże się odpowiednio duża, uzyskamy szeroką reprezentację społeczną, dzięki czemu można formułować wnioski na podstawie kryteriów socjolingwistycznych, takich jak wiek, płeć, wykształcenie, miejsce zamieszkania itp., podczas gdy w badaniach dialektologicznych analizy często w praktyce opierają się na pierwszym kryterium, a pozostałe są neutralizowane (nadreprezentacja kobiet, wykluczenie np. osób z wykształceniem wyższym i niezwiązanych z zawodami rolniczymi, mieszkańców miast). Należy jednak zwrócić uwagę, że korzystanie z ankiety internetowej sprzyja z kolei nadreprezentacji osób młodych i w średnim wieku oraz stawia przed badaczem konieczność dotarcia do osób starszych.

Uwzględnienie w badaniu świadomości językowej na temat gwary opinii nie tylko mieszkańców terenów wiejskich daje szerszą perspektywę. Oczywiście, opinie mieszkańców wsi na temat gwary są kluczowe, jednak sądy mieszkańców miasta mają pośredni wpływ na grupę pierwszą: dodatnie lub ujemne wartościowanie gwary przez miasto może wpływać na żywotność lub wypieranie gwary na wsi. 
Jak widać z powyższych uwag, ankieta internetowa daje nowe możliwości w badaniu świadomości językowej na temat gwary, ma jednak również pewne ograniczenia, z których należy zdawać sobie sprawę, gdy planuje się badanie albo analizuje jego wyniki.

\section{BIBLIOGRAFIA}

Bąk, P. 1955. „Formy wyśmiewane w gwarze okolic Kramska”. Rozprawy Komisji Językowej ŁTN 2: 235-245.

Bąk, P. 1960. Stownictwo gwary okolic Kramska na tle kultury ludowej. Wrocław: Zakład Narodowy im. Ossolińskich - Wydawnictwo PAN.

Bąk, P. 1968. Gwara okolic Kramska w powiecie konińskim. Zarys fonetyki i słowotwórstwa. Wrocław: Zakład Narodowy im. Ossolińskich.

Bąk, P. 1986. „Gwary województwa konińskiego”. W Województwo konińskie. Monografia regionalna. Zarys dziejów, obraz wspótczesny, perspektywy rozwoju. Łódź - Konin: Uniwersytet Łódzki, 114-123.

Budziszewska, W. 1957. Żargon ochweśnicki. Łódź - Wrocław: Zakład Narodowy im. Ossolińskich.

Cygan, S. 1993. „Różnice w mowie pokoleń na Kielecczyźnie”. W Polszczyzna Mazowsza i Podlasia. Różnice w mowie pokoleń, red. B. Bartnicka. Łomża: Łomżyńskie Towarzystwo Naukowe im. Wagów, 93-104.

Cygan, S. 2011. Przejawy świadomości językowej mieszkańców wsi końca XX wieku na przykładzie Lasocina na Kielecczyźnie. Kielce: Wydawnictwo Uniwersytetu Humanistyczno-Przyrodniczego Jana Kochanowskiego.

Dejna, K. 1993. Dialekty polskie. Wrocław: Zakład Narodowy im. Ossolińskich - Wydawnictwo.

Grochola-Szczepanek, H. 2008. „Stopień używania wyrazów ogólnopolskich i ich gwarowych odpowiedników - w ocenie młodych mieszkańców Spisza”. Język Polski 88 (3), 215-230.

Gruchmanowa, M. 2003. „Gwary wielkopolskie”. W M. Gruchmanowa, Gwary w ojczyźnie i na obczyźnie. Studia. Poznań: Wydawnictwo Studiów Polonistycznych, 118-156.

Karaś, H., red. Dialekty i gwary ... - Dialekty i gwary polskie. Kompendium internetowe. http://www.dialektologia.uw.edu.pl/index.php (7 marca 2021).

Kąś, J. 1994. Interferencja leksykalna słownictwa gwarowego i ogólnopolskiego (na przykładzie gwar orawskich). Kraków: Wydawnictwo Uniwersytetu Jagiellońskiego.

Krasowska, H. 2020. Języki mniejszości - status, prestiż, dwujęzyczność, wielojęzyczność. Warszawa: Studium Europy Wschodniej - Uniwersytet Warszawski.

Kucała, M. 1960. „O słownictwie ludzi wyzbywających się gwary”. Biuletyn Polskiego Towarzystwa Językoznawczego 19: 141-156.

Kucharzyk, R. 2002. „Język wsi z perspektywy autochtonów”. W Dialektologia jako dziedzina językoznawstwa i przedmiot dydaktyki. Księga jubileuszowa dedykowana profesorowi Karolowi Dejnie, red. S. Gala. Łódź: Łódzkie Towarzystwo Naukowe, 277-286.

Kucharzyk, R. 2011. „Badania świadomości językowej mieszkańców wsi”. Poradnik Językowy 4: 26-38.

Kucharzyk, R. 2015. „O postrzeganiu gwary przez użytkowników Internetu (na przykładzie forum tłumaczy)”. Prace Językoznawcze UWM 17 (2): 37-50. 
Kucharzyk, R. 2019. „Gwara - tradycja czy obciach? Spojrzenie młodych kobiet (na materiale z forów internetowych)". Poradnik Językowy 1: 7-19.

Kurek, H. 1995. Przemiany językowe wsi regionu krośnieńskiego. Studium socjolingwistyczne. Kraków: Towarzystwo Autorów i Wydawców Prac Naukowych „Universitas”.

Nitsch, K. 1957. Dialekty języka polskiego. Wrocław - Kraków: Zakład Narodowy im. Ossolińskich.

Nitsch, K. 1968. Wybór polskich tekstów gwarowych, wyd. 3 offsetowe, na podst. wyd. 2 zmien. przez autora. Warszawa: Państwowe Wydawnictwo Naukowe.

Osowski, B. 2015. „Projekt zbioru tekstów gwarowych ze wschodniej Wielkopolski. Między potrzebami językoznawców i nieprofesjonalistów". W Dialog pokoleń w języku potocznym, w języku wsi i miasta, w literaturze, w publicystyce, $w$ tekstach kultury, red. E. Wierzbicka-Piotrowska. Warszawa: Wydział Polonistyki Uniwersytetu Warszawskiego, 359-369.

Osowski, B. 2019. „Między wyjątkowością a wstydem. Świadomość językowa mieszkańców powiatu ostrowskiego". Gwary Dziś 11: 135-144.

Pelcowa, H. 2000. „Kompetencja językowa i kompetencja komunikacyjna mieszkańców wsi regionu lubelskiego". W Język polski. Wspótczesność - historia, red. W. Książek-Bryłowa, i H. Duda. Lublin: Wydawnictwo Uniwersytetu Marii Curie-Skłodowskiej, 91-104.

Pelcowa, H. 2004. „Wartościowanie gwary w wypowiedziach mieszkańców wsi”. Poznańskie Spotkania Językoznawcze 13: 127-139.

Piechnik, A. 2015. „Gwara w świadomości gimnazjalistów wiejskich”. W Dialog pokoleń w języku potocznym, w języku wsi i miasta, w literaturze, w publicystyce, w tekstach kultury, red. E. Wierzbicka-Piotrowska. Warszawa: Wydział Polonistyki Uniwersytetu Warszawskiego, 235-241.

Sierociuk, J. 2007. „Socjolingwistyczny kontekst badań języka mieszkańców wsi”. W Gwary dziś. 4. Konteksty dialektologii, red. J. Sierociuk. Poznań: Wydawnictwo Poznańskiego Towarzystwa Przyjaciół Nauk, 325-336.

Sobierajski, Z. 2001. „Geolingwistyka i geoetnologia w atlasie regionalnym Wielkopolski”. W Gwary dziś. 1. Metodologia badań, red. J. Sierociuk. Poznań: Wydawnictwo Poznańskiego Towarzystwa Przyjaciół Nauk, 67-94.

Tomaszewski, A. 1934. Mowa ludu wielkopolskiego. Charakterystyka ogólna. Z dwoma mapami. Poznań: na składzie w Księgarni Gebethnera i Wolffa czcionkami Drukarni Uniwersytetu Poznańskiego.

Urbańczyk, S. 1962. Zarys dialektologii polskiej, wyd. 2 zmien. i rozsz. Warszawa: Państwowe Wydawnictwo Naukowe.

WSPP - Markowski, A., red. 2004. Wielki stownik poprawnej polszczyzny PWN. Warszawa: Wydawnictwo Naukowe PWN.

Zagórski, Z. 1991. O mowie mieszkańców kilkunastu wsi wokót Konina. Wrocław: Zakład Narodowy im. Ossolińskich. 


\title{
Metalinguistic awareness about the dialect among the inhabitants of Konin region
}

Keywords: metalinguistic awareness, dialect, dialectology, sociolinguistics, Konin region.

\begin{abstract}
The paper shows the results of an internet survey on metalinguistic awareness about the dialect conducted among the inhabitants of Konin region (including towns and villages). It is an interesting area for sociological reasons (intensive development of the city in the 1960s and 1970s, rapid industrialization of the region and numerous migrations) and language (dialectal borderland and the influence of the language brought by former migrants). The attitudes of the respondents towards dialect were examined, how they evaluates this type of language and whether they use it. The analysis of 147 questionnaires makes it possible to take into account such criteria as age, sex, education and place of residence. An additional aim of the article is to formulate conclusions as to the use of an online survey in the study of language awareness about dialect.

Most of the opinions of the respondents are confirmed in the dialectological literature; On the other hand, the respondents did not observe any border features (mainly Mazovian influence) of the studied area. In the face of dialect, the respondents most often adopted a natural, liberal or laissez-faire attitude, while the young respondents were often characterized by an approach consistent with the category of exoticism.

With a sufficiently large research group, the survey obtains a broad social representation. Taking into account linguistic awareness of the dialect not only the opinions of rural residents gives a broader perspective.
\end{abstract}

